\title{
Level of auditory analysis, synthesis and active vocabulary and their intergender context
}

\section{[Uroven sluchovej analyzy, syntezy a aktivna slovna zasoba a ich mezipohlavny kontext]}

\author{
Jana Duchovicova - Nina Kozarova - Lukas Kurajda - Bade Bajrami - \\ Jerome Baghana
}

DOI: 10.18355/XL.2019.12.04.20

\begin{abstract}
The subject of our research were partial cognitive functions and phonematic awareness of preschool students. In our research, we found out that children who achieved higher level of active vocabulary also achieved higher level of auditory analysis and auditory synthesis. Following the findings, we focused on the identification of selected determinants of auditory analysis and synthesis, namely gender differences in the level of auditory analysis and active vocabulary of six-yearold children. Our aim was also to find out whether there is a difference in the level of auditory analysis and auditory synthesis in six-year-olds. Our results showed that the level of active vocabulary and auditory analysis in six-year-olds is not significantly different in gender, but there is a significant difference in the level of auditory analysis and auditory synthesis for this age group in favor of auditory analysis.

Key words: phonematic awareness, auditory analysis, auditory synthesis, active vocabulary, cognitive functions, reading literacy, strategies developing critical thinking
\end{abstract}

\begin{abstract}
Abstrakt
Predmetom nášho výskumu boli čiastkové kognitívne funkcie a fonematické uvedomovanie detí predškolského veku. V našom výskume sme zistili, že deti, ktoré dosiahli vyššiu úroveň aktívnej slovnej zásoby, dosiahli tiež vyššiu úroveň sluchovej analýzy a sluchovej syntézy. Nadväzujúc na predmetné zistenia sme sa zamerali na identifikáciu vybraných determinantov sluchovej analýzy a syntézy, konkrétne medzipohlavné rozdiely $\mathrm{v}$ úrovni sluchovej analýzy a aktívnej slovnej zásoby u šest'ročných detí. Naším ciel'om bolo tiež zistit', či existuje rozdiel v úrovni sluchovej analýzy a sluchovej syntézy u šest'ročných detí. Z našich výsledkov vyplynulo, že úroveň aktívnej slovnej zásoby a sluchovej analýzy u šest' ročných chlapcov a dievčat sa významne nelíši, ale existuje významný rozdiel v úrovni sluchovej analýzy a sluchovej syntézy u tejto vekovej skupiny v prospech sluchovej analýzy.
\end{abstract}

Kl'účové slová: fonematické uvedomovanie, sluchová analýza, sluchová syntézy, aktívna slovná zásoba, kognitívne funkcie, čitatel'ská gramotnost', stratégie rozvíjania kritického myslenia

\section{Úvod}

Schopnost' diet'at'a vnímat' jazyk ako štruktúru pozostávajúcu z obmedzeného súboru zvukov alebo foném môže byt' považovaný za jeden z najväčších koncepčných konštruktov l'udskej mysle. (Muntean, I., 2017).

Fonematické uvedomovanie je rozhodujúce pre učenie sa čítat' $\mathrm{v}$ abecedných jazykoch. Anthony a Francis (2005) tvrdia, že sa dosiahol konsenzus v otázke definície fonematického uvedomovania, pretože bola výskumne identifikovaná 
všeobecná postupnost' vývoja fonematického uvedomovania, ktorá je univerzálna vo všetkých jazykoch, hoci určité charakteristiky hovorených a písaných jazykov ovplyvňujú rýchlost' je normálneho vývoja. Fonematické uvedomovanie je chápané ako zručnost', ktorá umožňuje diet'at'u analyzovat' štruktúru zvukov jazyka (Schuele, Bourdeau, 2008). Predstavuje metalingvistickú schopnost' rozpoznávat' a manipulovat' so zvukovou štruktúrou slov, a to nezávisle od ich významu a na rôznom stupni jazykovej zložitosti (Phillips, Clancy-Menchetti, Lonigan, 2008). V teoretickom vymedzení fonematického uvedomenia popisuje J. M. Caroll (2001) dve základné roviny jeho chápania. Prvou je teória Goswami a Bryant (1990) založená na úrovni fonematického uvedomenia u detí predškolského veku a druhou je teória Gomert (1992) založená na epilingvistickom a metalingvistickom uvedomovaní. Základom fonematického uvedomenia je sluchová percepcia. Zvlášt' významná v predškolskom období je sluchová percepcia reči, ktorá bezprostredne súvisí s rozvojom vlastnej reči. Prostredníctvom sluchového vnímania si osvojuje diet’a materinský jazyk.

\section{Teoretické východiská}

Fonologické schopnosti, označované aj pojmom fonematické vedomie, či fonologické uvedomenie zahíňajú podl'a J. Josta (2011) fonologické uvedomovanie, krátkodobú fonologickú pamät' a modulačný faktor, ktorého sa týka schopnost' spracovávat' melódiu, intonáciu a rytmus hovorenej reči. Fonematické uvedomenie zahŕňa schopnost' analýzy (uvedomenie si rýmov, uvedomenie si slabík, fonémové uvedomenie) a schopnost' syntézy. Fonémové uvedomenie, ako faktor fonematického uvedomenia zahŕňa analýzu prvej hlásky v slove, analýzu poslednej hlásky v slove a analýzu prostrednej hlásky v slove.

Súčast’ou fonematického uvedomovania je fonematický sluch predstavujúci schopnost' rozlišovat' v slovách sluchom fonémy, ktoré majú významotvornú funkciu. Podl’a D. Kutálkovej (2005) zabezpečuje fonematický sluch spájanie hlások do slov a rozklad slova na hlásky, teda sluchovú analýzu a syntézu. Nedostatočne rozvinutý fonematický sluch je považovaný za jednu z hlavných príčin dyslexie. Sluchová analýza predstavuje schopnost' diet'at’a rozčlenit' verbálny prejav na menšie segmenty (vety, slová, slabiky a hlásky). Sluchová syntéza je procesom opačným. Základom je poznávacia myšlienková činnost', ktorá prebieha $\mathrm{v}$ nerozlučnej jednote každého poznávacieho aktu, jednotlivých poznávacích procesov vnímania, pocitovania, predstavovania, myslenia a jednotlivých myšlienkových operácií. (Macajova Grofcikova, Zajacova, 2017). Fonémy ako abstraktné jednotky jazyka sú dosiahnutel'né iba analýzou. Pri osvojovaní reči sa diet’a učí zvukovým celkom (slovám), ktoré sú spojené s významom. Fonéma je iba zlomkom tohto celku a nenesie žiadny význam (Jost, 2011). K predpokladom správnej sluchovej analýzy a syntézy je možné zahrnút' zrelost' diet'at'a, dosiahnutie potrebnej úrovne poznávacích procesov a systematického vnímania, kvalitu pozornosti, dobré zvládnutie jazyka a dobre zafixovanú slovná zásobu (Macajova, 2011). Pri syntéze nejde len o skladanie viet zo slov, či slov z hlások a slabík. Ide o spojenie dvoch procesov, a to slovného porozumenia (comprehension) a slovnej pohotovosti/ plynulosti (verbal fluency). Slovné porozumenie je úzko spojené s receptívnou, prijímajúcou schopnost'ou pochopit' hovorený a písaný jazykový vstup typu slov, viet a odstavcov a slovná pohotovost'/plynulost' je expresívna, vyjadrovacia schopnost' tvorby jazykového výstupu (Sternberg, 2009).

Štúdie Bradley a Bryant (1978) jednoznačne dokázali, že deti, ktoré majú problémy pri čítaní dosahujú nízku úroveň fonematického uvedomenia, čo zhodnotili ako príčinu ich problémov v oblasti čítania. K podobným výsledkom sa dopracovali aj Corriveau, Goswami a Thomson (2010). Pri výskume zručností ktorých nedostatočná úroveň môže predstavovat' riziko zlyhávania v učebnom výkone u detí predškolského veku. Zistili, že významnou zručnost'ou a determinantom včasného čítania je fonematické uvedomovanie. Fonologické uvedomovanie chápu ako komplexnú 
zručnost', ktorá sa prejavuje v podobe schopnosti rozpoznávat', rozlišovat' a manipulovat' so zvukmi v jednom jazyku. Fonologické povedomie pred nadobudnutím gramotnosti, ako konštatujú autori závisí od integrity sluchového spracovania nižšej úrovne. Ak dôjde k narušeniu sluchového spracovania jednotlivca, nie je možná presná reflexia zvukov $\mathrm{v}$ slovách, čo vedie k nesprávnemu fonologickému spracovaniu. Integrita sluchového spracovania je tak cenným ukazovatel'om odchýlok vo fonematickom uvedomovaní a čítaní. Tallal (1980), konštatuje že akustické informácie sú dočasné a časom sa menia, čo zistil pri prvých pokusoch spojit' sluchové spracovanie s fonologickými informáciami. Reč je komplexný akustický signál a modely sluchového spracovania reči sa postupne menia. Vzt'ah fonematického uvedomenia a úrovne neskoršieho čítania a písania potvrdili aj d’alšie štúdie (Bryant, Maclean, Bradley, Crossland, 1990; Cataldo a Ellis, 1988). Napríklad Cataldo a Ellis (1988) skúmali vzt’ahy medzi čítaním, pravopisom a fonologickým uvedomením v prvých troch rokoch školskej dochádzky. Úroveň fonamatického uvedomenia bola prediktorom neskoršieho vývoja čítania a pravopisu v každej fáze testovania. Tieto argumenty orientujú už dlhodobo záujem didaktikov pre hl'adanie spôsobov ako vhodne rozvíjat' fonematické uvedomovanie a tiež motivujú khl'adaniu prediktorov, ktoré ovplyvňujú úroveň fonematického uvedomovania. Rovnaké zistenia podáva i štúdia českých a anglických detí mladšieho školského veku (Caravolas, Volin, Hulme, 2005), kde v rámci výskumu sledovali rolu fonologického uvedomovania $\mathrm{v}$ rozvoji čítania a písania. U detí dvoch výrazne lingvisticky a ortograficky odlišných jazykov vo veku 7,5 - 11,5 roka testovali prediktívnu hodnotu fonologického uvedomovania pre písanie, rýchlost' čítania a porozumenie čítanému textu. Fonologické uvedomovanie sa ukázalo ako významný prediktor rozvoja rýchlosti čítania, správnosti písania a porozumenia čítanému textu.

Zo štúdie V. Muter, Ch. Hulme a M. J. Snowling (2004), je zrejmé, že fonologický subsystém jazyka ovplyvňuje predovšetkým počiatočný vývoj gramotnosti. Manipulícia s hláskami podl’a Adams (1990) si vyžaduje nielen rozpoznat' hlásky, z ktorých sa slovo skladá, ale hlásky aj vynechávat', zamieňat' a pod. Individuálne rozdiely $\mathrm{v}$ tejto schopnosti vynechávat', príp. zamieňat' hlásky v slovách, konštatuje Majova (2009), sú podstatnými ukazovatel'mi úrovne gramotných zručností, a to počas celej školskej dochádzky na prvom stupni. Z výskumu vynárajúcej sa gramotnosti u detí predškolského veku autorov G. Pinto, L. Bigozzi, C. Vezzani a C. Tarchi (2017) je zase zrejmé, že významným prediktorom pre osvojenie si procesu čítania je porozumenie spôsobu písania. Fonematické uvedomovanie má vplyv na čítanie, a to $\mathrm{z}$ dôvodu, že je integrované s porozumením a poznatkami príznačnými pre systém písania. Význam je pripisovaný rovnako aj sluchovej syntéze. Tento názor potvrdzuje longitudinálny výskum R. K. Wagner, J. K. Torgesen a C. A. Rashotte (1994). Autori označujú sluchovú analýzu a syntézu za klúčovú zručnost', ktorá ovplyvňuje schopnost' naučit' sa čítat'.

Holliman, Wood, Sheehy (2008) našli priame spojenie medzi citlivost'ou na rytmus reči u malých detí, fonologickým uvedomením a schopnost'ami číania. Dlhodobá štúdie zameraná na výskum fonematického uvedomovania v materských školách zdôrazňujú potrebu úplne porozumiet' vzt'ahu medzi zvukovým spracovaním a gramotnost'ou. Vychádzajúc $\mathrm{z}$ tejto potreby formulujeme aj naše výskumné zámery.

\section{Výskumný problém}

Predmetom nášho výskumu boli čiastkové kognitívne funkcie a fonematické uvedomovanie detí. Zo štúdie V. Muter, Ch. Hulme a M. J. Snowling (2004), je zrejmé, že fonologický subsystém jazyka ovplyvňuje predovšetkým počiatočný vývoj gramotnosti. Autori konštatujú, že prediktormi fonematickej citlivosti, teda rozpoznávania hlások sú poznávacie funkcie, schopnost' rozpoznávat' slová, aktívna slovná zásoba a gramatické zručnosti. K podobným výsledkom sme sa dopracovali aj

XLinguae, Volume 12, Issue 4, October 2019, ISSN 1337-8384, eISSN 2453-711X 
v našom výskume, z ktorého vyplynulo, že deti, ktoré dosiahli vyššiu úroveň aktívnej slovnej zásoby, dosiahli tiež vyššiu úroveň sluchovej analýzy a sluchovej syntézy. (Duchovicova a kol. 2019). Fonematické uvedomovanie má vplyv na čítanie, a to z dôvodu, že je integrované s porozumením a poznatkami príznačnými pre systém písania. Významným zistením je tiež skutočnost’, že delenie slov na slabiky a izolácia hlások, nesie „významnú mieru zodpovednosti za priebeh najranejších fáz nadobúdania čitatel'ských zručností“ (Majova, 2009). Význam je pripisovaný rovnako aj sluchovej syntéze. Tento názor potvrdzuje výskum R. K. Wagner, J. K. Torgesen a C. A. Rashotte (1994). Schopnost' čítat' je kl'účová v rozvoji čitatel'skej gramotnosti a táto je významným konštruktom kritického myslenia. V rozvíjaní kritického myslenia preto klúčovú úlohu hrajú okrem iných aj stratégie na rozvoj čitatel'ských zručností (Tomsik, Duchovicova, 2018).

Fonematické uvedomenie predstavuje metalingvistickú schopnost' rozpoznávat' a manipulovat' so zvukovou štruktúrou slov nezávisle od ich významu na rôznej úrovni zložitosti. Základom fonematického uvedomovania je sluchová analýza a syntéza a kjej diferenciácii dochádza v predškolskom veku. Ak sa u detí v predškolskom veku vyskytujú deficity $\mathrm{v}$ oblasti počutia, diferenciácie a analýzy zvukov reči, v školskom období sa môžu vyskytnút' problémy v osvojovaní si čítania a písaní. Preto sme sa v našom výskume zamerali na identifikáciu vybraných determinantov sluchovej analýzy a syntézy. Ciel'om bola identifikácia medzipohlavných rozdielov v úrovni sluchovej analýzy aktívnej slovnej zásoby u detí predškolského veku a rozdielu v úrovni sluchovej analýzy a syntézy. Z uvedeného ciel'a vyplynuli nasledovné výskumné problémy:

- Výskumný problém č. 1 Existujú medzipohlavné rozdiely v úrovni aktívnej slovnej zásoby a v úrovni sluchovej analýzy u 6 ročných detí?

- Výskumný problém č. 2 Existuje rozdiel v úrovni sluchovej analýzy a sluchovej syntézy и 6 ročných detí?

\section{Výskumné metódy}

Vol'ba testovacích nástrojov, ktoré nám umožnili identifikovat' úroveň fonematického uvedomovania detí vychádzala z analýzy Janeckovej (2014), ktorá zostavila logopédmi najčastejšie využívané diagnostické nástroje fonematického sluchu. $\mathrm{Na}$ základe posúdenia merných vlastností nástrojov a ich dostupnosti, sme zvolili ako testovací nástroj Z. Matejceka Skúšku sluchovej analýzy a syntézy (SAS). Na identifikáciu úrovne kognitívnych funkcií, konkrétne úrovne reči sme zvolili inteligenčný test WISC III, konkrétne subtest 8 Slovník (Wechsler, 2006). Ked’že nástroj je štandardizovaný pre vekovú skupinu min. 6 ročných detí, tento faktor ovplyvnil následne aj vekové zloženie testovaných detí.

Štatistické spracovanie dát bolo realizované prostredníctvom KolmogorovovhoSmirnovovho testu, ktorým sme overili normalitu dát, Pearsonovho koeficient korelácie, ktorým sme skúmali vzájomné vzt’ahy jednotlivých premenných a prostredníctvom Studentovho t-testu.

Výskum bol realizovaný $\mathrm{v}$ materských školách $\mathrm{v}$ Nitrianskom kraji, čo istým spôsobom limituje zovšeobecnitel'nost' výsledkov, no naše zistenia považujeme za pilotné pre skúmanie vzt'ahov úrovne kognitívnych funkcií a fonematického uvedomovania. Výber materských škôl bol dostupný a výber detí v týchto školách zámerný, pretože zaradené boli len deti, ktoré dosiahli vek 6 rokov. Výskumu sa zúčastnilo celkovo $58 \%$ dievčat a $42 \%$ chlapcov. Na zbere dat sa podielala $\mathrm{N}$. Pucekova.

\section{Analýza výsledkov}

Identifikované dáta sme spracovali prostredníctvom matematicko-štatistických metód. Normalita dát bola zist'ovaná pomocou Kolmogorovovho-Smirnovovho testu, na základe ktorého sme zistili, že dáta majú normálnu distribúciu (KS=0,085, p=0,200; 
$\mathrm{KS}=0,114, \mathrm{p}=0,091 ; \mathrm{KS}=0,139, \mathrm{p}=0,013)$ a pre d'alšie analýzy sme volili parametrické testy.

Tab 1 Normalita dát

\begin{tabular}{|l|l|l|l|}
\hline \multirow{2}{*}{ Premenné } & \multicolumn{3}{|l|}{ Kolmogorov-Smirnov } \\
\cline { 2 - 4 } & Statistic & $\mathbf{d f}$ & $\mathbf{p}$ \\
\hline Aktívna slovná zásoba & 0,085 & 52 & 0,200 \\
\hline Sluchová analýza & 0,114 & 52 & 0,091 \\
\hline Sluchová syntéza & 0,139 & 52 & 0,013 \\
\hline
\end{tabular}

Tab 2 Minimálny/maximálny počet bodov, priemer a štandardná odchýlka u všetkých detí

\begin{tabular}{|l|l|l|l|l|l|}
\hline Spolu & N & Minimum & Maximum & M & SD \\
\hline Aktívna slovná zásoba & 52 & 6 & 32 & 17,83 & 6,573 \\
\hline Sluchová analýza & 52 & 0 & 20 & 6,19 & 4,366 \\
\hline Sluchová syntéza & 52 & 0 & 18 & 5,35 & 4,934 \\
\hline
\end{tabular}

Výskumný problém č. 1 sme zamerali na zistenie existencie medzipohlavných rozdielov v úrovni aktívnej slovnej zásoby a v úrovni sluchovej analýzy u 6 ročných detí.

Prostredníctvom Studentovho t-testu sme porovnali dosiahnuté úrovne sluchovej analýzy a aktívnej slovnej zásoby u testovaných dievčat a chlapcov.

Tab 3 Medzipohlavné porovnanie vo faktore aktívna slovná zásoba

\begin{tabular}{|l|l|l|l|l|l|l|l|}
\hline \multicolumn{2}{|l|}{ Pohlavie } & N & M & SD & df & t & p \\
\cline { 1 - 8 } $\begin{array}{l}\text { Aktívna slovná } \\
\text { zásoba }\end{array}$ & CH & 22 & 17,68 & 6,945 & \multirow{2}{*}{50} & $-0,135$ & $\mathbf{0 , 8 9 3}$ \\
\cline { 2 - 6 } & D & 30 & 17,93 & 6,405 & & \\
\hline
\end{tabular}

*Pozn.: $N$-počet; $M$ - priemer; SD - štandardná odchýlka; $d f$ - stupne volnosti; $t$ Studentov t-test; $p$ - hladina signifikancie.

Tab 4 Medzipohlavné porovnanie vo faktore sluchová analýza

\begin{tabular}{|l|l|l|l|l|l|l|l|}
\hline \multicolumn{2}{|l|}{ Pohlavie } & N & M & SD & df & t & p \\
\cline { 1 - 8 } $\begin{array}{l}\text { Sluchová } \\
\text { analýza }\end{array}$ & CH & 22 & $\mathbf{6 , 5 9}$ & 4,963 & 50 & 0,560 & $\mathbf{0 , 5 7 8}$ \\
\cline { 2 - 8 } & D & 30 & $\mathbf{5 , 9 0}$ & 3,933 & &
\end{tabular}

*Pozn.: $N$-počet; $M$ - priemer; SD - štandardná odchýlka; $d f$ - stupne volnosti; $t$ Studentov t-test; $p$ - hladina signifikancie.

Na základe výskumu sme zistili, že v podstate existuje vel'mi malý, až zanedbatel'ný rozdiel medzi úrovňou aktívnej slovnej zásobu a sluchovej analýzy u šest'ročných chlapcov a dievčat.

Rozdiel, ktorý sme identifikovali je štatisticky bezvýznamný. Z uvedeného zistenia vyplýva, že medzipohlavné charakteristiky nepredstavujú významný faktor v oblasti fonematického uvedomovania a sekundárne nepredstavujú významný determinant rozvoja schopnosti čítat' a písat'. Tento výsledok je v súlade s hypotézou Hyde (2005) o rodových podobnostiach, ktorá tvrdí, že muži a ženy sú si vo väčšine psychologických premenných podobní, nie však všetci. To znamená, že muži a ženy, ako aj chlapci a dievčatá, sú si viac podobní, než 
odlišní a rodové rozdiely v kognícii sú iba malé. Podobné tvrdenia zastáva aj Halpern (2000), ktorá konštatuje že medzi mužmi a ženami existuje v úrovni kognitívnych schopností a všeobecnej inteligencie všeobecná zhoda. Rodové rozdiely sa obyčajne pozorujú pre konkrétnejšie kognitívne schopnosti ako sú vizuálne priestorové schopnosti (Voyer, Voyer a Bryden, 1995) a jazyk (Miller \& Halpern, 2013). Medzipohlavné rozdiely v čítaní a písaní sa však identifikujú v medzikultúrnych kontextoch (Lynn, Mikk, 2009; Reilly, 2012) a presahujú prahovú hodnotu, ktorú navrhli Hyde a Grabe (2008) pre netriviálne vel'kosti medzipohlavných rozdielov pohlaví $(\mathrm{d} \geq 0,10)$. Hyde $(2014)$ tiež identifikoval medzipohlavné rozdiely $\mathrm{v}$ úrovni čítania, ktoré sa ale líšia od minimálnych rozdielov v ostatných doménach verbálnych schopností (napr. slovnou zásobou, anagramami)v kultúrnych kontextoch.

Druhý výskumný problém v našej štúdii sme zamerali na zistenie existencie rozdielu v úrovni sluchovej analýzy a sluchovej syntézy u 6 ročných detí.

Tab 5 Porovnanie úrovne faktorov sluchová analýza a sluchová syntéza 6-ročných detí

\begin{tabular}{|l|l|l|l|l|l|l|}
\hline Premenné & $\mathbf{N}$ & $\mathbf{M}$ & SD & df & $\mathbf{t}$ & $\mathbf{p}$ \\
\hline Sluchová analýza & 52 & $\mathbf{6 , 1 9}$ & 4,366 & \multirow{2}{*}{51} & 10,228 & $\mathbf{0 , 0 0 0}$ \\
\hline Sluchová syntéza & 52 & $\mathbf{5 , 3 5}$ & 4,934 & & & \\
\hline
\end{tabular}

*Pozn.: N -počet; $M$ - priemer; SD - štandardná odchýlka; df - stupne vol’nosti; $t$ Studentov t-test; $p$ - hladina signifikancie.

Z našich zistení vyplynulo že deti predškolského veku dosahujú významne vyššiu úroveň sluchovej analýzy ako sluchovej syntézy. K podobným výsledkom sa dopracoval S. Cooke už v roku 1974. Sluchová diferenciácia sa rozvíja postupne, až ked' je ukončená základná schopnost' používat' reč spolu s jej gramatickými štruktúrami. Medzi 4 - 5 rokom začína diet’a rozlišovat' jednotlivé slová vo vete. $K$ rozvoju tejto schopnosti mu pomáhajú riekanky, ktoré rytmizujú reč a vetu rozdel'ujú na menšie časti. Okolo piateho roku začína diet’a vnímat' jednotlivé hlásky v slovách (ktorou hláskou slovo začína, neskôr ktorou končí). Najt’ažšie je určit' hlásku v strede slova. Ďalšou diskrimináciou vo vnímaní reči je vnímanie dížky samohlások a rozlišovanie tvrdých a mäkkých spoluhlások (6 - 7 rokov). Problémy v sluchovom vnímaní môžu viest' $\mathrm{k}$ rôznym t’ažkostiam, napríklad $\mathrm{k}$ neschopnosti zamerat' svoju pozornost' na jeden akustický podnet a vydiferencovat' ho od ostatných zvukov, k neschopnosti analyzovat' podobné zvuky, hlásky, slová, k neschopnosti analyzovat' vetu na slová, k zámene znelých a neznelých spoluhlások, k problémom so sluchovou analýzou a syntézou (neschopnost' rozložit' slovo na hlásky) spôsobené splývaním jednotlivých foném, $\mathrm{k}$ nedostatočnej sluchovej diferenciácii mäkkých a tvrdých hlások. Problémy v sluchovej pamäti sa môžu prejavit' neschopnost'ou zapamätat' si obsah alebo formu počutého. (Pokorna, V., 2010)

Záver: Fonologické uvedomovanie hrá podl'a J.L. Anthony a D.J. Francis (2005) dôležitú úlohu pri získavaní gramotnosti. Predstavuje súhrn rôznych fonologických schopností, ktoré sa objavujú v predvídatel'nom poradí. Spolu s genetikou, inteligenciou, pamätou a slovnou zásobou ovplyvňujú rýchlost' $s$ akou jednotlivci dosahujú skúsenosti s orálnym a písaným jazykom. Ďalší výskum fonematického uvedomovania má významné dôsledky na hodnotenie fonologického vedomia, diagnostikovanie kognitívnych funkcií relevantných pre dosiahnutie úspechu vo 
vzdelávaní, či včasnú intervenciu zameranú na predchádzanie poruchám učenia. V uvedenom kontexte sme uskutočnili výskum vybraných kognitívnych funkcií (aktívna slovná zásoba) a faktorov fonematického uvedomovania (sluchová analýza a sluchová syntéza). Náš výskum u slovenských 6-ročných detí potvrdil významný pozitívny vzt’ah medzi úrovňou aktívnej slovnej zásoby a sluchovej analýzy, ako aj aktívnej slovnej zásoby a úrovne sluchovej syntézy. Vychádzajúc z uvedeného sme d’alej v predmetnej štúdii identifikovali neexistenciu medzipohlavných rozdielov v úrovni sluchovej analýzy a aktívnej slovnej zásoby u detí predškolského veku a významný rozdiel v úrovni faktorov fonematického uvedomenia. Slovenské 6-ročné deti dosiahli štatisticky významne vyššiu úroveň sluchovej analýzy ako sluchovej syntézy. Stimulácia sluchovej analýzy a syntézy u detí v predškolskom veku môže významne ovplyvnit' konkrétne fonologické zručnosti, stratégie čítania, či kvalitu osvojovania si pravopisu (Anthony, J.L., Francis, D.J., 2005), preto sú systematicky vyvíjané rôzne stratégie či aplikácie na rozvoj fonematického uvedomovania v rámci rozvoja jazyka a komunikácie. Odporúčame napr. Muntean, I., 2017; Baezzat F, et al., 2018; Mușuțan, L.A. 2017, Mikulajova, M. a kol., 2018 a i. Programov pre materské školy zamerané na rozvoj gramotnosti, fonematického uvedomovania a rozvoj jazyka je v ponuke množstvo, je teda na učitel'kách, aby sa stimulácia slovnej zásobya sluchovej analýzy a syntézy u detí stala neoddelitel'nou súčastou vzdelávacieho programu, ktorý vo svojej každodennej edukačnej činnosti aplikujú. Štúdia súvisí s výskumom a zámermi projektu s názvom Vývoj diagnostického nástroja na hodnotenie úrovne fonematického uvedomovania u detí v predškolskom veku.

Táto práca bola podporovaná Agentúrou na podporu výskumu a vývoja na základe Zmluvy č. APVV-15-0368.

\section{Bibliographic references}

ADAMS, M. J. 1990. Beginning to read: Thinking and learning about print. Cambridge, MA: MIT Press.

ANTHONY, J. - FRANCIS, D. 2005. Development of Phonologi-cal https://doi.org/10.1111/j.0963-7214.2005.00376.x

BAEZZAT, .F, et al. 2018.The Effect of Phonological Awareness on the Auditory Memory in Students With Spelling Problems. In IRJ, vol. 16, n. 1 pp. 83-90.

BRADLEY, L. - BRYANT, P. 1978. Difficulties in auditory organisation as a possible cause of reading backwardness. Nature, 271, 746-747.

BRYANT, P.E. - MACLEAN, M. - BRADLEY, L.L. - CROSSLAND, J. 1990. Rhyme and Alliteration, Phoneme Detection, and Learning to Read. In Developmental Psychology, vol. 26, n. 3, pp. 429-438, DOI: 10.1037/0012-1649.26.3.429.

CARAVOLAS, M. - VOLIN, J. - HULME, C. 2005. Phoneme awareness is akey component of alphabetic literacy skills in consinent and inconsistent orthographies: Evidence from Czech 86 an English children. In Journal of Experimental Child Psychology. vol. 92, no. 2, pp. 107-139.

CARROL, J. M. 2001. The Development of Phonological Awareness in Pre-school Children. A thesis submitted for the degree of Doctor of Philosophy. University of York, departmen of psychology, 230 p. Available online: http://etheses.whiterose.ac.uk/9761/1/251812.pdf

CATALDO, Z. - ELLIS, N. 1988. Interactions in the development of spelling, reading and phonological skills. In Journal of Research in Reading, vol 11, n.2, pp. 89-109.

COOKE, S. 1974. Auditory Vocal Analysis and Synthesis Skills of Learning Disabled Children.In American Speech and Hearing Association, Las Vegas, Nevada, Available online: https://files.eric.ed.gov/fulltext/ED107075.pdf 
CORRIVEAU, K. H. - GOSWAMI, U. - THOMSON, J. M. 2010. Auditory Processing and Early Literacy Skills in a Preschool and Kindergarten Population. In Journal of Learning Disabilities, vol. 43, n. 4, pp. 369-382, DOI: $10.1177 / 0022219410369071$

DUCHOVICOVA a kol. 2019. Phonematic Awareness and Chosen Cognitive Functions of a Child.

GOMBERT, J. E. 1992. Metalinguistic Development. Chicago: Harvester Wheatsheaf.

GOSWAMI, U. - BRYANT, P. E. 1990. Phonological Skills and Learning to Read. Hove, East Sussex: Psychology Press.

HALPERN, D. F. 2000. Sex Differences in Cognitive Abilities (3rd ed.). Mahwah, NJ: Erlbaum.

HAROUN, Z. 2018. The pedagogical device, framework of analysis of the teaching process and evaluation of the reading comprehension. In XLinguae, vol. $11 \mathrm{n}$. 1XL, pp. 138-149, ISSN 1337-8384, DOI: 10.18355/XL.2018.11.01XL.12

HOLLIMAN, A. J. - WOOD, C. - SHEEHY, K., 2008. Sensitivity to speech rhythm explains individual differences in reading ability independently of phonological awareness. In British Journal of Developmental Psychology, vol. 26, n. 3, pp. 357367.

HYDE, J. S. 2005. The gender similarities hypothesis. In American Psychologist, vol. 60, n. 6, p. 581-592. doi: 10.1037/0003-066X.60.6.581

HYDE, J. S. - GRABE, S. 2008. Meta-analysis in the psychology of women. In F. Denmark \& M. A. Paludi (Eds.), Psychology of women: a handbook of issues and theories. pp. 142-173. Westport, CT: Praeger Publishers.

HYDE, J. S. 2014. Gender similarities and differences. In Annual Review of Psychology, vol. 65, n. 1, p. 373-398. doi: 10.1146/annurev-psych-010213-115057.

JANECKOVA, S. 2014. Testove materialy vyuzivane v logopedicke intervenci. Bakalárska práca. Vedúci bakalárskej práce Lucie Durdilová. Praha: Univerzita Karlova v Praze.

JOST, J. 2011. Ctení a dyslexie. Praha : Grada Publishing. ISBN 978-80-247-3030-1.

KUTALKOVA, D. 2005. Vyvoj detske reci krok za krokem. Praha : Grada Publishing. ISBN 80-247-1026-9.

LYNN, R. - MIKK, J. 2009. Sex differences in reading achievement. In Trames, vol. 13, n. 1, pp. 3-13. doi: 10.3176/tr.2009.1.01

MACAJOVA, M. 2011. Jazykova gramotnost : teorie a metody jej rozvoja. Nitra: Univerzita Konstantina Filozofa. ISBN 978-80-558-0005-9.

MACAJMACAJOVA, M. - GROFCIKOVA, S. - ZAJACOVA, Z. 2017. Fonologicke uvedomovanie ako prekurzor vyvinu gramotnosti. Nitra: UKF. ISBN 978-80-558-1212-0

MAJOVA, L. 2009. Fonologicke dovednosti a jejich vyznam v pocatecnich fazich rozvoje cteni. In Pedagogika, vol. 59, n. 1, pp. 17-23.

MIKULAJOVA, M. Ed. 2018. Utvaranie ranej gramotnosti v norme a patologii. Brno : Institut vzdelavani Sokrates, 188 p. ISBN 978-80-86572-82-6.

MILLER, D. I. - HALPERN, D. F. 2013. The new science of cognitive sex differences. In Trends in Cognitive Sciences, vol.18, n. 1, pp. 37-45. DOI: 0.1016/j.tics.2013.10.011

MUȘUȚAN, L.A. 2017. Strategies to empower phonemic hearing in the context of intellectual disability. In RRTTCL, vol. 3, n. 2, DOI: 10.26744/rrttlc.2017.3.2.03

MUNTEAN, I. 2017. Developing phonological awarness at pre-school age In RRTTCL, 2017, vol. 3, n. 2 , DOI: 10.26744/rrttlc.2017.3.2.05

MUTER, V. - HULME, C. - SNOWLING, M. J. - STEVENSON, J., 2004. Phonemes, Rimes, Vocabulary, and Grammatical Skills as Foundations of Early Reading Development: Evidence From a Longitudinal study. In: Developmental Psychology, vol. 40, n. 5, pp. 665-681. DOI: 10.1037/0012-1649.40.5.665 
PHILLIPS, B. M. - CLANCY-MENCHETTI, J. - LONIGAN, C. J. 2008. Successful phonological awareness instruction with preschool children: Lessons from the classroom. In Topics in Early Childhood Special Education, vol. 28, pp. 3-17. doi: 10.1177/0271121407313813.

PINTO, G. - BIGOZZI, L. - VEZZANI, C. - TARCHI, C. 2017. Emergent literacy and reading acquisitio: alongitudinal study from kindergarten to primary schol. In European Journal of Psychology of Education. Florence : Department of Education and Psychology, vol. 32, n. 4, pp. 571-587.

POKORNA, V. 2010. Vyvojove poruchy uceni v detstvi a dospelosti. Praha: Portal. ISBN 978-80-7367-773-2.

PUCEKOVA, N. 2018. Kognitivne funkcie dietata a fonematicke uvedomovanie. Diplomova praca. Skolitel: Jana Duchovicova, Nitra: PF UF v Nitre, 60 p.

SCHUELE, C. M. - BOUDREAU, D. 2008. Phonological awareness intervention: Beyond the basics. Language. In Speech, and Hearing Services in Schools, vol. 39, n. 1, pp. 3-20. DOI: 10.1044/0161-1461(2008/002)

REILLY, D. 2012. Gender, culture and sex-typed cognitive abilities. In PLoS ONE, vol. 7, n. 7, doi: 10.1371/journal.pone.0039904

STERNBERG, R. J. 2009. Kognitivni psychologie. Praha : Portál. ISBN 978-807367-638-4.

TALLAL, P. 1980. Auditory temporal perception, phonics, and read-ing disabilities in children. In Brain and Language, vol. 9, n. 2, pp.182-198

TOMSIK, R. - DUCHOVICOVA, J. 2018. Managerial Competencies of a Teacher in the Context of Learners' Critical Thinking Development: Exploratory Factor Analysis of a Research Tool and the Results of the Research. In. TEM Journal. - ISSN 22178309, vol. 7, n. 2, pp. 335-347.

VOYER, D. - VOYER, S. - BRYDEN, M. P. 1995. Magnitude of sex differences in spatial abilities: A meta-analysis and consideration of critical variables. In Psychological Bulletin, vol. 117, n. 2, pp. 250-270. doi: 10.1037//00332909.117.2.250

WAGNER, R. K. - TORGESEN, J. K. - RASHOTTE, C. A. 1994. Development of reading-related phonological processing abilities: New evidence of bidirectional causality from a latent variable longitudinal study. Developmental Psychology, 30(1), pp. 73-87.

WECHSLER, D. 2006. WISC-IIISK. Wechslerova inteligencna skala pre deti. Autori slovenskej verzie V. Dockal, E. Kretova, B. Kundratova, B. Sedlacova, M. Tesar. Praha : Hogrefe - Testcentrum.

Words: 4082

Characters: 29544 (16,41 standard pages)

doc. PaedDr. Jana Duchovičová, PhD.

Nina Kozárová, $\mathrm{PhD}$.

Department of Pedagogy

Faculty of Education

Constantine the Philosopher University in Nitra

Dražovská cesta 4

94974 Nitra

Slovakia

jduchovicova@ukf.sk

XLinguae, Volume 12, Issue 4, October 2019, ISSN 1337-8384, eISSN 2453-711X 
dr. Bade Bajrami

Prishtina University

Kosovo

Dr. Lukas Kurajda

University of Ss. Cyril and Methodius in Trnava

Nám. J. Herdu 2

91701 Trnava

Slovakia

Prof. Dr. Jérôme Baghana, Dr.

Belgorod State University

University of Ss. Cyril and Methodius in Trnava

Nám. J. Herdu 2

91701 Trnava

Slovakia 